\title{
Diallel Analysis of Bacterial Wilt Resistance in Tomato Derived from Different Sources
}

Peter M. Hanson, Asian Vegetable Research and Development Center (AVRDC) Shanhua, Taiwan, Republic of China; Olivia Licardo, Institute of Plant Breeding, University of the Philippines, Los Baños; Hanudin, Segunung Horticultural Research Station, Java, Indonesia; Jaw-Fen Wang and Jen-tzu Chen, Asian Vegetable Research and Development Center (AVRDC) Shanhua, Tainan 741, Taiwan, Republic of China

\begin{abstract}
Hanson, P. M., Licardo, O., Hanudin, Wang, J. F., and Chen, J.-T. 1998. Diallel analysis of bacterial wilt resistance in tomato derived from different sources. Plant Dis. 82:74-78.

Bacterial wilt, caused by Ralstonia solanacearum, is a major constraint to tomato production in the tropics and subtropics. Most bacterial wilt-resistant tomato cultivars have not shown consistently high resistance levels over locations. The objective of this study was to determine whether combining resistance derived from different sources would result in $F_{1}$ progenies with resistance greater than that of the parents. Five bacterial wilt-resistant tomato lines or accessions (CL5915, L285, CRA84, H7997, and GA219), each derived from different resistance sources, and a susceptible processing tomato line (UC204A) were crossed in all combinations without reciprocals. Parents, $F_{1}$ progenies, and $F_{2}$ progenies were evaluated in greenhouses at three locations (Taiwan, Philippines, and Indonesia) for percent survival 6 weeks after drench inoculation with virulent local strains of $R$. solanacearum. Percent survival means over locations were 17.4 to 83.0 for parents and $F_{1}$ progeny and 16.2 to 75.0 for parents and $F_{2}$ progeny. The percent survival means over locations of L285 $\times \mathrm{H} 7997$ were highest among crosses in the $F_{1}$ (83.0) and $F_{2}$ (75.0) generations but were not significantly greater than that of H7997. Highly significant mean squares were found in the $\mathrm{F}_{1}$ and $\mathrm{F}_{2}$ progenies for general combining ability (GCA) and GCA $\times$ locations. Positive GCA effects over locations were detected for H7997, CRA84, and L285, indicating that progeny with those lines as parents showed bacterial wilt resistance that was greater than the average of all crosses. Only H7997, however, had positive GCA effects estimates at each location for each generation, and its GCA effects estimates over locations were significantly greater than those of the other parents in the $F_{1}$ and $F_{2}$ progenies. Among this set of parents, $\mathrm{H} 7997$ is the best source to develop bacterial wilt-resistant progeny. We did not observe statistically significant increases in resistance by combining different resistance sources. However, the presence of large GCA variances suggests that hybridization of parents that have high GCA for bacterial wilt resistance, such as H7997, CRA84, or L285, followed by selection in segregating populations might yield inbred progeny with resistance greater than that of the parents.
\end{abstract}

Ralstonia solanacearum (Smith) Smith, the soilborne pathogen that causes bacterial wilt (BW) in tomato (Lycopersicon esculentum Mill.), is endemic in the tropics and subtropics. Disease control is difficult because of the broad host range, widespread distribution, and vast genetic variability of the pathogen (12). Consequently, $\mathrm{BW}$ resistance should be a component of tropical tomato cultivars. Often, however, tomato cultivars resistant to $\mathrm{BW}$ at one location have been susceptible at other locations $(11,27)$. Virulence differences among pathogen strains can cause resistance instability $(5,18)$, although other

Corresponding author: P. Hanson

E-mail: hansp@netra.avrdc.org.tw

Accepted for publication 23 September 1997.

Publication no. D-1997-1118-01R

(C) 1998 The American Phytopathological Society biotic and abiotic factors affect host resistance (12). Instability of BW resistance complicates the development of resistant tomato cultivars, necessitating extensive multilocation testing.

The BW resistance in cultivated tomato originated from L. esculentum var. cerasiforme or L. pimpinellifolium (17). Resistance in most current BW-resistant tomato cultivars can be traced to one of three major sources. (i) PI127805A (L. pimpinellifolium), first identified at the University of Hawaii, was the donor of BW resistance in Kewalo (7). Highly resistant lines Hawaii 7996, Hawaii 7997, and Hawaii 7998 are thought to have derived from PI127805A, although this is not certain ( $\mathrm{J}$. Scott, personal communication). (ii) CRA66 (L. esculentum var. cerasiforme), a smallfruited landrace found by researchers at the Institut National de la Recherche Agronomique (INRA) in the French West Indies, was the resistance source in Caraibo and Caravel (17). (iii) PI129080 (L. pimpinel- lifolium) and Beltsville \#3814, which were the sources for the "North Carolina" resistance, were used to develop BW-resistant cultivars Venus and Saturn (13) and possibly North Carolina breeding lines BW2 and BW4. BW2 and Roma VF were the sources of BW resistance in Rodade (2), and BW4 was the source of resistance in Rotam 4 (8).

Additional BW resistance sources have been identified but have not been extensively exploited, primarily because of their small fruit sizes and poor horticultural characters. These accessions include L285 (11) and selections from wild tomato accessions PI263722, PI126408, PI196298 (L. esculentum), and PI251323 (L. pimpinellifolium) (14).

Reports on the genetic control of BW resistance among different sources vary both in the number of genes and the types of gene action involved. Acosta et al. (1) concluded that resistance in 5808-2, a selection from PI127805A, showed partial dominance early in the season. A single dominant gene for BW resistance was reported in Hawaii 7998 (19) and in Hawaii 7996 (10). Important resistance quantitative trait loci in $\mathrm{H} 7996$ were detected on chromosomes six and four as well as additional lesser quantitative trait loci $(25,26)$. Polygenic BW resistance has been reported for CRA 66 (17) and the North Carolina resistance derived from PI129080 and Beltsville \#3814 (22). Two genomic regions on chromosomes six and ten showing partial dominance for BW resistance were found in L285 (4).

Since BW resistance originated from $L$. esculentum and from wild Lycopersicon species more genetically diverse than cultivated tomato, the presence of different genes or alleles conditioning BW resistance is likely. This research was undertaken to determine whether combining BW-resistant parents originally derived from different resistance sources would result in $F_{1}$ progenies with higher resistance levels and to estimate general and specific combining abilities for BW resistance in this set of resistance sources.

\section{MATERIALS AND METHODS}

Parents and crosses. Five BW-resistant inbred lines derived from different resis- 
tance sources and UC204A, a BW-susceptible processing tomato line, were selected as parents. The BW-resistant lines and the original resistance source of each were as follows: (i) CL5915-93D $4-1-0-3$ (CL5915), a small-fruited, determinate, heat-tolerant line bred at the Asian Vegetable Research and Development Center (AVRDC) with BW resistance derived from Saturn, and UPCA1169, a bred line from the University of the Philippines (11); (ii) L285, an indeterminate L. esculentum var. cerasiforme accession from Taiwan maintained at the AVRDC Genetic Resources and Seed Unit that has shown relatively high BW resistance in multilocation trials conducted in Southeast Asia (11); (iii) CRA84-58-1 (CRA84), a determinate, large-fruited line bred in Guadeloupe by INRA with BW resistance derived from CRA66 (CRA84 was among the most resistant entries in multilocation BW trials in Southeast Asia) (11); (iv) GA219, a small-fruited, indeterminate selection from PI126408 (L. esculentum) that has shown high BW resistance levels in Florida tests $(20,23)$; and (v) Hawaii 7997 (H7997), a medium-fruited, semideterminate plant type with a high level of BW resistance $(19,20,27)$, presumably derived from PI127805A (L. pimpinellifolium).

The six parents were crossed in all combinations without reciprocals to produce $15 \mathrm{~F}_{1}$ single crosses. Bulk $\mathrm{F}_{2}$ seed from each cross was obtained by selffertilization of $F_{1}$ plants. Two experiments were conducted to evaluate treatments. The first experiment included the $15 \mathrm{~F}_{1}$ crosses and six parents, and the second experiment included the $15 \mathrm{~F}_{2}$ crosses and six parents.
In both experiments, treatments were arranged according to a randomized complete block design with three replications. Experimental units included 12 plants of each parent and 24 plants of each cross, except at AVRDC, where plots of parents and crosses contained 48 plants.

Treatments were evaluated for BW reactions in greenhouses at three locations: AVRDC, Taiwan; Institute of Plant Breeding, University of the Philippines, Los Baños; and Segunung Horticultural Research Station, Java, Indonesia. Experiments 1 and 2 were conducted once at each location. Seedlings were grown individually in plastic pots $(170-\mathrm{ml}$ volume at AVRDC; 220-ml volume at the Philippines and Indonesia). The potting soil mixture, consisting of sand, soil, rice husks, and compost (1:3:1:1), was pasteurized with steam prior to use.

Inoculation. At each location, treatments were inoculated with one highly virulent $R$. solanacearum strain isolated locally from infected tomato plants. Strains used for inoculation were Pss4 (Taiwan), T22 (Philippines), and Tom22 (Indonesia); all strains were identified as race 1 , biovar 3. Because of quarantine regulations, exchange of strains and testing of all strains in the same experiment at one location were not possible. For inoculum preparation, strain cultures stored in $30 \%$ glycerol at $-80^{\circ} \mathrm{C}$ or in water at room temperature were streaked on tetrazolium chloride medium (16). Several fluidal colonies were transferred to plates containing 523 media (15) for multiplication at $30^{\circ} \mathrm{C}$ for $24 \mathrm{~h}$. Bacterial cells were harvested with glass slides, suspended in water, and adjusted to $\mathrm{OD}_{600}=0.3$, (about $\left.10^{8} \mathrm{CFU} / \mathrm{ml}\right)$. Imme- diately before inoculation, inoculum was further diluted to $1 \times 10^{6} \mathrm{CFU} / \mathrm{ml}$. Fourweek-old seedlings, approximately in the five-leaf stage, were inoculated by pouring $30 \mathrm{ml}\left(20 \mathrm{ml}\right.$ at Taiwan) of $1 \times 10^{6}$ inoculum on the soil surface at the base of each plant. Plant roots were not wounded before inoculation. Mean greenhouse temperatures during the trials (from inoculation until the last evaluation) were 25.7 to $32.2^{\circ} \mathrm{C}$ during the day and 20 to $25.0^{\circ} \mathrm{C}$ at night.

Disease evaluation and data analysis. Treatments were evaluated for wilting at weekly intervals for 6 weeks, beginning 1 week after inoculation. Wilted plants invariably died, so plants were judged as either healthy or wilted. Percent survival was determined for each experimental unit on the basis of the last evaluation in each experiment. Prior to analysis, percent survival data were transformed by the arcsine of the square root to normalize the scale. Analyses of variance of percent survival means of crosses and parents for each location and over locations were carried out separately for parents and $F_{1}$ progeny and parents and $F_{2}$ progeny. The model for the analysis of variance over locations assumed parents and crosses to be a fixed effect and locations a random effect. Parents and cross means were separated by Waller-Duncan $(K=100)$ with appropriate error terms. Heterosis was measured at each location as the difference in percent survival between each $F_{1}$ progeny and its respective high (most resistant) parent within replications. Statistical significance of differences was tested by $t$ test (24).

Combining ability analyses of $F_{1}$ and $F_{2}$ crosses were conducted separately accord-

Table 1. Percent survival means of parents and $F_{1}$ progenies, and parents and $F_{2}$ progenies evaluated for bacterial wilt resistance at Taiwan, the Philippines, and Indonesia ${ }^{\mathrm{z}}$

\begin{tabular}{|c|c|c|c|c|c|c|c|c|}
\hline \multirow[b]{2}{*}{ Parent/cross } & \multicolumn{4}{|c|}{ Parents and $F_{1}$} & \multicolumn{4}{|c|}{ Parents and $F_{2}$} \\
\hline & Taiwan & Philippines & Indonesia & Combined & Taiwan & Philippines & Indonesia & Combined \\
\hline CRA 84 & $66.7 \mathrm{~cd}$ & $36.1 \mathrm{~b}-\mathrm{f}$ & $91.7 \mathrm{ab}$ & $64.8 \mathrm{c}-\mathrm{e}$ & $55.5 \mathrm{a}-\mathrm{c}$ & $77.8 \mathrm{ab}$ & $91.7 \mathrm{bc}$ & $75.0 \mathrm{a}$ \\
\hline UC204A & $7.6 \mathrm{i}$ & $16.7 \mathrm{e}-\mathrm{g}$ & $27.8 \mathrm{~g}-\mathrm{i}$ & $17.4 \mathrm{j}$ & 2.81 & $34.7 \mathrm{c}-\mathrm{f}$ & $11.1 \mathrm{k}$ & $16.2 \mathrm{f}$ \\
\hline H7997 & $76.4 \mathrm{~b}-\mathrm{d}$ & $61.1 \mathrm{a}-\mathrm{c}$ & $91.7 \mathrm{ab}$ & $76.4 \mathrm{ab}$ & $69.7 \mathrm{a}$ & $19.4 \mathrm{ef}$ & $100.0 \mathrm{a}$ & $63.1 \mathrm{a}-\mathrm{c}$ \\
\hline CL5915 & $22.2 \mathrm{gh}$ & $11.1 \mathrm{~g}$ & $66.7 \mathrm{c}-\mathrm{e}$ & $33.3 \mathrm{hi}$ & $26.5 \mathrm{~g}-\mathrm{i}$ & $11.1 \mathrm{f}$ & $38.9 \mathrm{ij}$ & $25.5 \mathrm{~d}-\mathrm{f}$ \\
\hline GA219 & $37.5 \mathrm{fg}$ & $36.1 \mathrm{~b}-\mathrm{f}$ & $33.3 \mathrm{f}-\mathrm{i}$ & $35.6 \mathrm{~h}$ & $15.4 \mathrm{ij}$ & $27.8 \mathrm{~d}-\mathrm{f}$ & $58.3 \mathrm{f}-\mathrm{h}$ & $33.8 \mathrm{~b}-\mathrm{f}$ \\
\hline $\mathrm{L} 285$ & $84.0 \mathrm{ab}$ & $52.8 \mathrm{a}-\mathrm{d}$ & 50.0 ef & $62.3 \mathrm{c}-\mathrm{e}$ & $30.9 \mathrm{f}-\mathrm{h}$ & $13.9 \mathrm{f}$ & $91.7 \mathrm{bc}$ & $45.5 \mathrm{a}-\mathrm{f}$ \\
\hline CL5915 × L285 & $61.1 \mathrm{de}$ & $58.3 \mathrm{a}-\mathrm{d}$ & $68.1 \mathrm{c}-\mathrm{e}$ & $62.5 \mathrm{c}-\mathrm{e}$ & $30.4 \mathrm{f}-\mathrm{h}$ & $77.8 \mathrm{ab}$ & $63.9 \mathrm{e}-\mathrm{h}$ & $57.3 \mathrm{a}-\mathrm{e}$ \\
\hline CL5915 × CRA84 & $64.6 \mathrm{~d}$ & $30.5 \mathrm{c}-\mathrm{g}$ & $93.1 \mathrm{ab}$ & $62.7 \mathrm{c}-\mathrm{e}$ & $31.9 \mathrm{e}-\mathrm{h}$ & $51.4 \mathrm{~b}-\mathrm{e}$ & $98.6 \mathrm{a}$ & $60.6 \mathrm{a}-\mathrm{c}$ \\
\hline CL5915 × H7997 & $75.0 \mathrm{~b}-\mathrm{d}$ & $44.4 \mathrm{~b}-\mathrm{e}$ & $93.0 \mathrm{ab}$ & $70.8 \mathrm{bc}$ & $51.4 \mathrm{~b}-\mathrm{d}$ & $55.6 \mathrm{~b}-\mathrm{d}$ & $97.2 \mathrm{ab}$ & $68.1 \mathrm{a}-\mathrm{c}$ \\
\hline CL5915 × GA219 & $39.6 \mathrm{f}$ & $27.8 \mathrm{~d}-\mathrm{g}$ & $51.7 \mathrm{~d}-\mathrm{f}$ & $39.7 \mathrm{gh}$ & $27.2 \mathrm{~g}-\mathrm{i}$ & $57.0 \mathrm{~b}-\mathrm{d}$ & $54.1 \mathrm{~g}-\mathrm{i}$ & $46.1 \mathrm{a}-\mathrm{f}$ \\
\hline CL5915 × UC204A & $11.1 \mathrm{hi}$ & $32.0 \mathrm{~b}-\mathrm{g}$ & $45.8 \mathrm{fg}$ & $29.6 \mathrm{hi}$ & $6.9 \mathrm{kl}$ & $51.4 \mathrm{~b}-\mathrm{e}$ & $45.8 \mathrm{hi}$ & $34.7 \mathrm{c}-\mathrm{f}$ \\
\hline L285 × CRA84 & $80.6 \mathrm{a}-\mathrm{c}$ & $57.0 \mathrm{a}-\mathrm{d}$ & $93.0 \mathrm{ab}$ & $76.9 \mathrm{ab}$ & $47.2 \mathrm{~b}-\mathrm{d}$ & $76.4 \mathrm{ab}$ & $80.6 \mathrm{c}-\mathrm{e}$ & $68.1 \mathrm{a}-\mathrm{c}$ \\
\hline $\mathrm{L} 285 \times \mathrm{H} 7997$ & $89.6 \mathrm{a}$ & $63.9 \mathrm{ab}$ & $95.6 \mathrm{a}$ & $83.0 \mathrm{a}$ & $61.1 \mathrm{ab}$ & $77.8 \mathrm{ab}$ & $86.1 \mathrm{~cd}$ & $75.0 \mathrm{a}$ \\
\hline $\mathrm{L} 285 \times \mathrm{GA} 219$ & $63.2 \mathrm{~d}$ & $77.8 \mathrm{a}$ & $40.3 \mathrm{f}-\mathrm{h}$ & $60.4 \mathrm{~d}-\mathrm{f}$ & $38.9 \mathrm{~d}-\mathrm{g}$ & $82.0 \mathrm{ab}$ & $70.8 \mathrm{~d}-\mathrm{g}$ & $63.9 \mathrm{a}-\mathrm{c}$ \\
\hline $\mathrm{L} 285 \times \mathrm{UC} 204 \mathrm{~A}$ & 44.5 ef & $44.4 \mathrm{~b}-\mathrm{e}$ & $26.4 \mathrm{hi}$ & $38.4 \mathrm{~h}$ & $11.8 \mathrm{jk}$ & $70.8 \mathrm{ab}$ & $59.7 \mathrm{f}-\mathrm{h}$ & $47.5 \mathrm{a}-\mathrm{f}$ \\
\hline CRA84 × H7997 & $73.6 \mathrm{~b}-\mathrm{d}$ & $36.1 \mathrm{~b}-\mathrm{f}$ & $94.4 \mathrm{ab}$ & $68.1 \mathrm{~b}-\mathrm{d}$ & $46.5 \mathrm{~b}-\mathrm{e}$ & $68.0 \mathrm{a}-\mathrm{c}$ & $97.2 \mathrm{ab}$ & $70.6 \mathrm{a}$ \\
\hline CRA $84 \times$ GA219 & $66.0 \mathrm{~d}$ & $27.8 \mathrm{~d}-\mathrm{g}$ & $77.8 \mathrm{c}$ & 57.2 ef & $44.7 \mathrm{c}-\mathrm{f}$ & $55.6 \mathrm{~b}-\mathrm{d}$ & $73.6 \mathrm{~d}-\mathrm{f}$ & $58.0 \mathrm{a}-\mathrm{e}$ \\
\hline CRA84 × UC204A & $33.3 \mathrm{fg}$ & $13.9 \mathrm{e}-\mathrm{g}$ & $70.8 \mathrm{~cd}$ & $39.3 \mathrm{~h}$ & $16.7 \mathrm{ij}$ & $15.3 \mathrm{~d}-\mathrm{f}$ & $63.9 \mathrm{e}-\mathrm{h}$ & $32.0 \mathrm{c}-\mathrm{f}$ \\
\hline H7997 × GA219 & $69.4 \mathrm{~b}-\mathrm{d}$ & $52.8 \mathrm{a}-\mathrm{d}$ & $80.6 \mathrm{bc}$ & $67.6 \mathrm{~b}-\mathrm{e}$ & $46.1 \mathrm{~b}-\mathrm{e}$ & $58.3 \mathrm{~b}-\mathrm{d}$ & $77.8 \mathrm{c}-\mathrm{f}$ & $60.7 \mathrm{a}-\mathrm{d}$ \\
\hline H7997 × UC204A & $36.1 \mathrm{fg}$ & $31.9 \mathrm{~b}-\mathrm{g}$ & $80.6 \mathrm{bc}$ & $49.5 \mathrm{fg}$ & $24.3 \mathrm{hi}$ & $93.1 \mathrm{a}$ & $80.6 \mathrm{c}-\mathrm{e}$ & $66.0 \mathrm{a}-\mathrm{c}$ \\
\hline GA219 × UC204A & $14.6 \mathrm{hi}$ & $26.4 \mathrm{~d}-\mathrm{g}$ & $20.8 \mathrm{i}$ & $20.6 \mathrm{ij}$ & 4.91 & $41.6 \mathrm{~b}-\mathrm{f}$ & $23.6 \mathrm{jk}$ & $23.4 \mathrm{ef}$ \\
\hline Mean & 53.2 & 39.9 & 66.3 & 53.2 & 32.9 & 53.2 & 69.8 & 52.0 \\
\hline
\end{tabular}

${ }^{\mathrm{z}}$ Mean separation by Waller-Duncan $(K$ ratio $=100)$. Data were transformed to the arcsine of the square root for analysis. Nontransformed means are shown. Means within columns followed by the same letter are not significantly different. 
ing to Griffing (9) by using experimental method 4 (crosses only) and model 1 (fixed effects). Combining ability analyses over locations were carried out as described by Singh (21). For each parent in this diallel, five of the 15 crosses had that line as one of its parents. General combining ability (GCA) is the average of all $F_{1}$ or $F_{2}$ crosses sharing a common parent expressed as a deviation from the overall mean of all crosses $(3,6)$. GCA assessed the value of a parental line for $\mathrm{BW}$ resistance on the basis of the mean performance of its progeny. An expected value for each $F_{1}$ or $F_{2}$ cross was estimated on the basis of the GCA of its parents, and specific combining ability (SCA) was calculated to determine whether $F_{1}$ or $F_{2}$ performance exceeded or fell below the expected value $(3,6)$. Combining ability analysis was used to break down variance resulting from crosses into GCA and SCA components. GCA and SCA effects were calculated if their respective mean squares were significant in the analysis of variance. In this study, a positive GCA effect indicated that BW resistance of crosses with that line as a parent was better than the average. Similarly, a positive SCA effect arose if resistance of a cross was better than predicted on the basis of parental reactions.

\section{RESULTS}

Parents and cross means. Wilted plants were observed in all parental lines at each location, demonstrating that parents were not immune to BW. Some researchers regard "tolerance" as a better term to describe BW resistance $(17,25)$. Over locations and experiments (Table 1), parental lines $\mathrm{H} 7997$ and CRA84 gave the highest percent survival means $(69.8$ and 69.9, respectively) followed by L285 (53.9), GA219 (34.7), CL5915 (29.4), and UC204A (16.8). Parental means varied greatly

Table 2. Differences between $F_{1}$ progeny and high parent means for bacterial wilt percent survival evaluated at greenhouses in Taiwan, the Philippines, and Indonesia ${ }^{z}$

\begin{tabular}{lcccccc}
\hline & \multicolumn{6}{c}{ Parent } \\
\cline { 2 - 7 } Location & Parent & L285 & CRA84 & H7997 & GA219 & UC204A \\
\hline Taiwan & CL5915 & $-22.9^{*}$ & -2.1 & -1.4 & 2.1 & -11.1 \\
Philippines & & 5.5 & -5.6 & -16.7 & -8.3 & 15.3 \\
Indonesia & & 1.4 & 1.4 & 1.3 & $-15.0^{* *}$ & $-20.9^{*}$ \\
Taiwan & L285 & $\ldots$ & -3.4 & 5.6 & -20.8 & $-39.5^{*}$ \\
Philippines & & $\ldots$ & 4.2 & 2.8 & 25.0 & -8.4 \\
Indonesia & & $\ldots$ & 1.3 & 3.9 & -9.7 & -23.6 \\
Taiwan & CRA84 & $\ldots$ & $\ldots$ & -2.8 & 0.7 & -33.4 \\
Philippines & & $\ldots$ & $\ldots$ & -25.0 & -8.3 & -22.2 \\
Indonesia & & $\ldots$ & $\ldots$ & 2.8 & -13.9 & $-20.9^{*}$ \\
Taiwan & \multirow{H}{*}{ H7997 } & $\ldots$ & $\ldots$ & $\ldots$ & -7.0 & -40.3 \\
Philippines & & $\ldots$ & $\ldots$ & $\ldots$ & -8.3 & $-29.2^{*}$ \\
Indonesia & & $\ldots$ & $\ldots$ & $\ldots$ & -11.1 & -11.1 \\
Taiwan & \multirow{2}{*}{ GA219 } & $\ldots$ & $\ldots$ & $\ldots$ & $\ldots$ & -22.9 \\
Philippines & & $\ldots$ & $\ldots$ & $\ldots$ & $\ldots$ & -9.7 \\
Indonesia & & $\ldots$ & $\ldots$ & $\ldots$ & $\ldots$ & -12.5 \\
\hline
\end{tabular}

${ }^{\mathrm{z}}$ Differences calculated as $\mathrm{F}_{1}-\mathrm{HP}$ within blocks, where HP is the percent survival of the most resistant parent of that $\mathrm{F}_{1}$ progeny. Significance of the difference was tested by $t$ test. $* *=$ Significant at $P<0.01$, and $*=$ significant at $P<0.05$.

among locations. For example, percent survival of $\mathrm{H} 7997$ over $\mathrm{F}_{1}$ and $\mathrm{F}_{2}$ experiments was $73.1,40.3$, and 95.9 at Taiwan, the Philippines, and Indonesia, respectively. Furthermore, reactions of several parents were inconsistent between experiments at the same location, notably L285 at all locations and CRA84 and H7997 in the Philippines. By conducting experiments in the greenhouse instead of the field, we reduced environmental variation caused by pathogen strains, soil type, and moisture levels, which can affect resistance (12). However, since the parental lines were inbreds, variation of parental reactions between experiments at the same location inoculated with the same strain suggests that environmental factors, possibly temperature, affected disease reactions.

Mean percent survival of crosses ranged from 20.6 to 83.0 in the $F_{1}$ and 23.4 to 75.0 in the $\mathrm{F}_{2}$ progenies (Table 1). Among crosses, L285 $\times$ H7997 produced the highest mean percentage of resistant progeny over locations in both the $F_{1}$ (83.0) and the $F_{2}$ (75.0) generations, but these means were not significantly greater than those of H7997. $F_{1}$ and $F_{2}$ progenies of L285 $\times$ CRA84, CRA84 × H7997, and CL5915 $\times$ H7997 also ranked among the most resistant crosses at each location. Over locations, the $F_{1}$ and $F_{2}$ means of all crosses with $\mathrm{H} 7997$ as one parent (67.8 and 68.1 in the $F_{1}$ and $F_{2}$, respectively) were greater than the progeny means of the other parents. $F_{1}$ and $F_{2}$ progeny means were 64.2 and 62.4, respectively, for L285 and 60.8 and 57.9, respectively, for CRA84. As expected, high proportions of wilted plants were found in crosses with UC204A as a parent, except for $\mathrm{H} 7997 \times \mathrm{UC} 204 \mathrm{~A}$ in Indonesia, where $F_{1}$ and $F_{2}$ means of this cross exceeded the location means in each experiment. It is possible that resistance to the Indonesian strain is simply inherited or

76 Plant Disease/Vol. 82 No. 1 that UC204A contributed alleles enhancing resistance to the Indonesian strain. Cases of BW-susceptible tomato lines passing genes to progeny that improved BW resistance have been reported $(2,4)$.

Each $F_{1}$ progeny was compared with its respective high parent (most resistant) at each location to measure heterosis, which was judged present when the percent survival mean of the $F_{1}$ progeny significantly exceeded that of the high parent. None of the $F_{1}$ crosses demonstrated significantly greater survival than its high parent (Table 2 ), and most $F_{1}$ means, in fact, fell below that of its high parent. $F_{1}$ progeny means of L285 $\times$ H7997 were slightly greater than that of the high parent at each location (L285 at Taiwan; H7997 at the Philippines and Indonesia), but the differences were small (2.8 to 5.6$)$ and not statistically significant.

Combining ability analyses. We found significant mean squares for locations, crosses, GCA over locations, and the GCA $\times$ location interaction for the $F_{1}$ and $F_{2}$ progenies (Table 3). SCA mean squares over locations and the SCA $\times$ location interaction were significant in the $F_{2}$ but not in the $F_{1}$ progenies. In the combined analysis of variance, GCA mean squares exceeded SCA mean squares by almost 40 times in the $F_{1}$ and seven times in the $F_{2}$ progenies. The larger magnitude of GCA compared with SCA mean squares suggests that among this group of parents, expression of $\mathrm{BW}$ resistance is primarily the result of additive gene action and $F_{1}$ and $F_{2}$ progeny performance could be predicted from mean parental reactions (3). This is in agreement with González and Summers (8), who also found GCA mean squares that were 3 to 15 times greater than SCA mean squares for BW resistance in tomato.

Positive estimates of GCA effects over locations were found for H7997, CRA84, and L285 in both the $F_{1}$ and $F_{2}$ progenies (Table 4). A positive GCA effect indicated that percent survival means from crosses that included one of the above parents was higher than the average of all crosses (6).

Table 3. Mean squares from diallel analyses of $\mathrm{F}_{1}$ and $\mathrm{F}_{2}$ generations evaluated for bacterial wilt reaction in greenhouses in Taiwan, the Philippines, and Indonesia ${ }^{y}$

\begin{tabular}{lrccc}
\hline & df & $\mathbf{F}_{\mathbf{1}}$ & $\mathbf{F}_{\mathbf{2}}$ \\
\hline Location (L) & 2 & $3,934.4^{* *}$ & $8,633.9^{* *}$ \\
Rep/L & 6 & 142.1 & 176.7 \\
Crosses (C) & 14 & $1316.8^{* *}$ & $1064.1^{* *}$ \\
$\quad$ GCA $^{\mathrm{z}}$ & 5 & $3,525.8^{* *}$ & $2374.0^{* *}$ \\
$\quad$ SCA & 9 & 89.5 & $336.4^{* *}$ \\
C $\times$ L & 28 & $348.4^{* *}$ & $325.2^{* *}$ \\
$\quad$ GCA $\times$ L & 10 & $831.9^{* *}$ & $632.9^{* *}$ \\
$\quad$ SCA $\times$ L & 18 & 79.8 & $154.2^{* *}$ \\
Error & 84 & 56.8 & 86.4 \\
\hline
\end{tabular}

${ }^{y}$ Data were transformed to the arcsine of the square root for analysis. $* *=$ Significant at $P<0.01$, and $*=$ significant at $P<0.05$.

${ }^{\mathrm{z}} \mathrm{GCA}=$ general combining ability, and $\mathrm{SCA}=$ specific combining ability. 
In contrast, negative GCA effects were estimated for CL5915, GA219, and UC204A across locations in the $F_{1}$ and $F_{2}$ progenies. GCA effects for L285 were positive at Taiwan and the Philippines in the $F_{1}$ and $F_{2}$ generations but negative at Indonesia for both generations. Similarly, GCA effects estimates in both the $F_{1}$ and $\mathrm{F}_{2}$ progenies for CRA84 were positive at Taiwan and Indonesia but negative at the Philippines. Inconsistent GCA effects estimates among parents over locations would explain the presence of highly significant GCA $\times$ location mean squares (Table 3 ). SCA mean squares were significant at Indonesia in the $F_{1}$ and $F_{2}$ progenies, the Philippines in the $F_{2}$ progenies, and combined over locations in the $\mathrm{F}_{2}$ progenies (Table 4). L285 $\times$ H7997 in the $\mathrm{F}_{2}$ progenies showed a negative SCA effect, which would indicate that the percent survival mean from this cross was less than would be expected on the basis of reactions of the parents.

\section{DISCUSSION}

The biological reasons for the failure of entries (parents and crosses) to perform similarly with respect to each other between locations remain unclear because parents and crosses were tested in different greenhouses with different pathogen strains.
It is clear from the work of Elphinstone (5) that genotype $\times$ strain interactions are a major cause of instability in BW resistance in tomato, and the variable reactions among parents and crosses among locations probably results in part from differences in virulence among the strains used. As previously mentioned, however, the inconsistent performance of genetically uniform parents between experiments at the same location suggests that environmental factors also affected resistance.

We observed a close correspondence between percent survival means of parents over locations and sizes of their GCA effects. Four parents in this study (H7997, L285, GA219, and CL5915) are among the 35 entries in the International Set of Resistance Sources to Bacterial Wilt in Tomato, a worldwide collaboration to test available BW resistance sources over locations (27). The ranking of these four parents for percent survival over nine trials in seven countries (27) was almost identical to their ranking according to magnitude of GCA effects in this study. This ongoing effort to evaluate the International Set will provide useful information on the stability of different BW resistance sources and may indicate the value of the entries as parents in developing resistant progeny.
H7997, CRA84, and L285 would be the best BW resistance sources among this set of parents. CRA84 is particularly useful for breeding because it yields large, moderately firm fruit while H7997 and L285 have medium and small fruit, respectively, and their fruit tend to crack. GCA effects over locations for H7997 were significantly greater than those of the other parents in both generations, and only H7997 consistently produced positive GCA estimates at each location. Although $\mathrm{H} 7997$ has poor fruit quality, low fruit set, and other undesirable characteristics, it appears to be a good parent to develop resistant lines. González and Summers (8) noted that Hawaii 7998 (H7998), a BW-resistant line related to H7997 (J. Scott, personal communication), was the only parent in their diallel experiment that produced a relatively greater proportion of resistant $\mathrm{F}_{1}$ progeny when tested against seven $R$. solanacearum strains. Hawaii 7996, H7997, and H7998, all presumably derived from PI127805A, were among the most resistant and stable entries in the International Set (27) and showed consistently high survival in multiple-year tests in Florida (20). Achievement of broad-based resistance is more likely when H7997 or other Hawaii lines are used as parents. Because of the

Table 4. GCA ${ }^{\mathrm{u}}$ and $\mathrm{SCA}^{\mathrm{v}}$ effects of $\mathrm{F}_{1}$ and $\mathrm{F}_{2}$ crosses evaluated for bacterial wilt reactions at greenhouses in Taiwan, the Philippines, and Indonesia

\begin{tabular}{|c|c|c|c|c|c|c|c|c|}
\hline & \multicolumn{4}{|c|}{$\mathbf{F}_{1}$} & \multicolumn{4}{|c|}{$\mathbf{F}_{2}$} \\
\hline & Taiwan & Philippines & Indonesia & Combined & Taiwan & Philippines & Indonesia & Combined \\
\hline \multicolumn{9}{|l|}{ Parent, GCA effects } \\
\hline CL 5915 & -3.97 & -1.97 & 1.45 & -1.50 & -2.52 & -2.53 & 2.69 & -0.79 \\
\hline L285 & 10.99 & 14.50 & -3.22 & 7.42 & 4.81 & 11.86 & -1.53 & 5.05 \\
\hline CRA84 & 6.59 & -7.26 & 13.85 & 4.39 & 4.81 & -7.66 & 11.15 & 2.76 \\
\hline H7997 & 11.44 & 3.62 & 18.20 & 11.09 & 11.29 & 7.29 & 14.56 & 11.05 \\
\hline GA219 & -3.79 & 1.06 & -12.80 & -5.17 & -0.52 & -3.48 & -11.40 & -5.13 \\
\hline UC204A & -21.26 & -9.95 & -17.48 & -16.23 & -17.87 & -5.48 & 15.47 & -12.94 \\
\hline $\operatorname{LSD}_{0.05}\left(g_{\mathrm{i}}-g_{\mathrm{j}}\right)^{\mathrm{w}}$ & 5.15 & 7.52 & 6.20 & 3.60 & 5.07 & 10.59 & 6.18 & 4.43 \\
\hline \multicolumn{9}{|l|}{ Cross, SCA effects } \\
\hline CL5915 × L285 & $\ldots{ }^{x}$ & $\ldots$ & -0.89 & $\ldots$ & $\ldots$ & 4.06 & -8.07 & $\ldots$ \\
\hline CL5915 × CRA84 & $\ldots$ & $\ldots$ & 1.33 & $\ldots$ & $\ldots$ & 2.92 & 12.11 & $\ldots$ \\
\hline CL5915 × H7997 & $\ldots$ & $\ldots$ & 0.09 & $\ldots$ & $\ldots$ & -9.58 & 4.75 & $\ldots$ \\
\hline CL5915 × GA219 & $\ldots$ & $\ldots$ & -0.89 & $\ldots$ & $\ldots$ & 1.91 & -4.02 & $\ldots$ \\
\hline CL5915 × UC 204A & $\ldots$ & $\ldots$ & 0.36 & $\ldots$ & $\ldots$ & 0.69 & -4.77 & $\ldots$ \\
\hline L285 × CRA84 & $\ldots$ & $\ldots$ & 6.32 & $\ldots$ & $\ldots$ & 3.64 & -5.85 & $\ldots$ \\
\hline L285 × H7997 & $\ldots$ & $\ldots$ & 4.64 & $\ldots$ & $\ldots$ & -9.97 & -4.65 & $\ldots$ \\
\hline L2 $285 \times$ GA219 & $\ldots$ & $\ldots$ & -2.91 & $\ldots$ & $\ldots$ & 3.52 & 10.83 & $\ldots$ \\
\hline $\mathrm{L} 285 \times \mathrm{UC} 204$ & $\ldots$ & $\ldots$ & -7.17 & $\ldots$ & $\ldots$ & -1.25 & 7.75 & $\ldots$ \\
\hline CRA84 × H7997 & $\ldots$ & $\ldots$ & -13.78 & $\ldots$ & $\ldots$ & 4.91 & -3.70 & $\ldots$ \\
\hline CRA $84 \times$ GA219 & $\ldots$ & $\ldots$ & 3.48 & $\ldots$ & $\ldots$ & 6.53 & -0.14 & $\ldots$ \\
\hline $\mathrm{CRA} 84 \times \mathrm{UC} 204 \mathrm{~A}$ & $\ldots$ & $\ldots$ & 2.66 & $\ldots$ & $\ldots$ & -18.00 & -2.42 & $\ldots$ \\
\hline H7997 × GA219 & $\ldots$ & $\ldots$ & 2.61 & $\ldots$ & $\ldots$ & -7.94 & -1.26 & $\ldots$ \\
\hline $\mathrm{H} 7997 \times \mathrm{UC} 204 \mathrm{~A}$ & $\ldots$ & $\ldots$ & 6.44 & $\ldots$ & $\ldots$ & 22.58 & 4.86 & $\ldots$ \\
\hline GA219 $\times$ UC204A & $\ldots$ & $\ldots$ & -2.29 & $\ldots$ & $\ldots$ & -4.02 & -5.42 & $\ldots$ \\
\hline $\operatorname{LSD}_{0.05}\left(s_{\mathrm{ij}}-s_{\mathrm{ik}}\right)^{\mathrm{y}}$ & $\ldots$ & $\ldots$ & 10.57 & $\ldots$ & $\ldots$ & 18.35 & 10.71 & $\ldots$ \\
\hline $\operatorname{LSD}_{0.05}\left(s_{\mathrm{ij}}-s_{\mathrm{lk}}\right)^{\mathrm{z}}$ & $\ldots$ & $\ldots$ & 8.79 & $\ldots$ & $\ldots$ & 15.00 & 8.75 & $\ldots$ \\
\hline
\end{tabular}

" General combining ability, the average bacterial wilt survival of all $\mathrm{F}_{1}$ or $\mathrm{F}_{2}$ crosses sharing that common parent, expressed as a deviation from the overall mean of all crosses. A positive GCA effect indicates that the percent survival mean from crosses that included that parent was higher than the average of all crosses.

${ }^{v}$ Specific combining ability, which measures whether actual $F_{1}$ or $F_{2}$ performance of a cross performed better or worse than expected on the basis of the GCA values of the parents. A positive SCA effect indicates that the $F_{1}$ and $F_{2}$ progenies were more resistant that expected on the basis of the average GCA of the parents.

${ }^{\mathrm{w}}$ Least significant difference for comparisons between GCA effects.

${ }^{x}$ SCA effects were not calculated because the SCA mean square in the analysis of variance was not significant.

${ }^{y}$ Least significant difference for comparisons between SCA effects with a common parent.

${ }^{\mathrm{z}}$ Least significant difference for comparisons between SCA effects with no common parent. 
importance of the genotype $\times$ environment interaction for $\mathrm{BW}$ resistance, multilocation testing of progenies would be essential for the identification of stable BW-resistant lines.

None of the $F_{1}$ progeny in this study that were developed by crossing lines derived from different BW resistance sources demonstrated significantly higher resistance than its respective high parent. Identification of $F_{1}$ progeny with greater $\mathrm{BW}$ resistance than the better parents, H7997, L285, and CRA84, would have been desirable. Development of $F_{1}$ hybrids with enhanced $\mathrm{BW}$ resistance by combining the resistance sources used in this study appears to be unlikely. The large GCA to SCA variance ratios indicate the importance of additive and additive $\times$ additive gene effects in governing resistance (3). Consequently, crossing parents with positive GCA for BW and recurrent selection to accumulate resistance alleles may be one way to boost resistance beyond levels present in existing resistance sources (3). Intercrossing parents that show large positive GCA effects, such as H7997, L285, and CRA84, followed by selfing and selection for resistance in segregating populations might yield progeny with superior $\mathrm{BW}$ resistance.

\section{ACKNOWLEDGMENTS}

Journal paper 160 of the Asian Vegetable Research and Development Center. This research was funded by the Asian Development Bank and the Asian Vegetable Research and Development Center.

\section{LITERATURE CITED}

1. Acosta, J. C., Gilbert, J. C., and Quinon, V. L. 1964. Heritability of bacterial wilt resistance in tomato. Proc. Am. Soc. Hortic. Sci. 84:455462.

2. Bosch, S. E., Louw, A. J., and Aucamp, E. 1985. 'Rodade' bacterial wilt resistant tomato. HortScience 20:458-459.

3. Christie, B. R., and Shattuck, V. I. 1992. The diallel cross: Design, analysis, and use for plant breeders. Pages 9-36 in: Plant Breeding Reviews, vol. 9. J. Janick, ed. John Wiley \&
Sons, New York.

4. Danesh, D., Aarons, S., McGill, G. E., and Young, N. D. 1994. Genetic dissection of oligogenic resistance to bacterial wilt in tomato. Mol. Plant-Microbe Interact. 7:464471.

5. Elphinstone, J. G. 1994. Virulence of isolates of Pseudomonas solanacearum from worldwide sources on resistant and susceptible tomato cultivars. Pages 599-604 in: Proc. Int. Conf. Plant Pathog. Bact., 8th. Institut National de la Recherche Agronomique, Paris.

6. Falconer, D. S. 1989. Introduction to Quantitative Genetics. 3rd ed. Longman Scientific and Technical, Hong Kong. pp. 275-277.

7. Gilbert, J. C., Tanaka, J. S., and Takeda, K. Y. 1973. 'Kewalo' tomato. HortScience 9:481482.

8. González, W. G., and Summers, W. L. 1995. A comparison of Pseudomonas solanacearum-resistant tomato cultivars as hybrid parents. J. Am. Soc. Hortic. Sci. 120:891-895.

9. Griffing, B. 1956. Concept of general and specific combining ability in relation to diallel crossing systems. Aust. J. Biol. Sci. 9:463-493

10. Grimault, V., Prior, P., and Anais, G. 1995. A monogenic dominant resistance of tomato to bacterial wilt in Hawaii 7996 is associated with plant colonization by Pseudomonas solanacearum. J. Phytopathol. 143:349-352.

11. Hanson, P. M., Wang, J. F., Licardo, O., Hanudin, Mah, S. Y., Hartman, G. L., Lin, Y. C., and Chen, J. T. 1996. Variable reaction of tomato lines to bacterial wilt evaluated at several locations in Southeast Asia. HortScience 31:143-146.

12. Hayward, A. C. 1991. Biology and epidemiology of bacterial wilt caused by Pseudomonas solanacearum. Annu. Rev. Phytopathol. 29:65-87.

13. Henderson, W. R., and Jenkins, S. F., Jr. 1972. 'Venus' and 'Saturn' tomato varieties resistant to southern bacterial wilt. HortScience 7:346.

14. Jaworski, C. A., Phatak, S. C., Gate, S. R., Gitaitis, R. D., and Widrlechner, M. P. 1987. GA 1565-2-4, GA 219-1-2 BWT, GA 1095-14 BWT, and GA 1405-1-2 BWT bacterial wilt-tolerant tomato. HortScience 22:324-325.

15. Kado, C. I., and Heskett, M. G. 1970. Selective media for isolation of Agrobacterium, Corynebacterium, Erwinia, Pseudomonas, and Xanthomonas. Phytopathology 60:969976.

16. Kelman, A. 1954. The relationship of pathogenicity in Pseudomonas solanacearum to colony appearance on a tetrazolium medium. Phytopathology 44:693-695.

17. Prior, P., Grimault, V., and Schmit, J. 1994 Resistance to bacterial wilt (Pseudomonas solanacearum) in tomato: Present status and prospects. Pages 209-223 in: Bacterial Wilt: The Disease and its Causative Agent Pseudomonas solanacearum. A. C. Hayward and G. L. Hartman, eds. CAB International, Wallingford, England.

18. Prior, P., Steva, H., and Cadet, P. 1990 Aggressiveness of strains of Pseudomonas solanacearum from the French West Indies (Martinique and Guadeloupe) on tomato Plant Dis. 74:962-965.

19. Scott, J. W., Somodi, G. C., and Jones, J. B. 1988. Bacterial spot resistance is not associated with bacterial wilt resistance in tomato. Proc. Fla. State Hortic. Soc. 101:390-392.

20. Scott, J. W., Somodi, G. C., and Jones, J. B. 1993. Testing tomato genotypes and breeding for resistance to bacterial wilt in Florida. Pages 126-131 in: Bacterial Wilt. G. L. Hartman and A. C. Hayward, eds. Australian Centre for International Agricultural $\mathrm{Re}$ search, Canberra.

21. Singh, D. 1973. Diallel analysis for combining ability over several environments. II. Indian J. Plant Breed. Genet. 33:469-481.

22. Singh, K. 1961. Inheritance of North Carolina type of bacterial wilt resistance in tomato, Lycopersicon esculentum. M.S. thesis. University of Hawaii, Honolulu.

23. Sonoda, R. M., and Augustine, J. 1978. Reaction of bacterial wilt-resistant tomato lines to Pseudomonas solanacearum in Florida. Plant Dis. Rep. 62:464-466.

24. Steel, R. G. D., and Torrie, J. H. 1980. Principles and Procedures of Statistics. 2nd ed. McGraw-Hill, New York. pp. 102-104.

25. Thoquet, P., Olivier, J., Sperisen, C., Rogowsky, P., Laterrot, H., and Grimsley, N. 1996. Quantitative trait loci determining resistance to bacterial wilt in the tomato cultivar Hawaii 7996. Mol. Plant-Microbe Interact. 9:826836.

26. Thoquet, P., Olivier, J., Sperisen, C., Rogowsky, P., Prior, P., Anaïs, G., Mangin, B., Bazin, B., Nazer, R., and Grimsley, N. 1996. Polygenic resistance of tomato plants to bacterial wilt in the French West Indies. Mol. PlantMicrobe Interact. 9:837-842.

27. Wang, J. F., Hanson, P. M., and Barnes, J. A 1996. Preliminary results of worldwide evaluation of international set of resistance sources to bacterial wilt in tomatoes. Bact. Wilt Newsl. 13:8-10. 